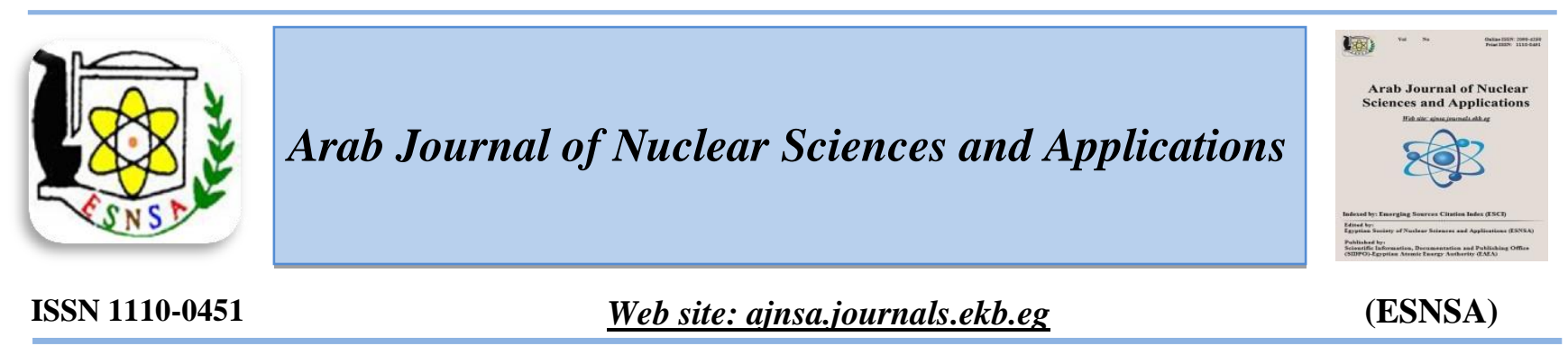

\title{
Assessment of Radiological Hazard Indices in Abu Rusheid Area, South Eastern Desert, Egypt, Using Gamma Ray Spectroscopy
}

\author{
Hesham A. Yousef ${ }^{(1)}$, Hamed. I. Mira ${ }^{(2)}$, and K. A. Korany ${ }^{(2)}$ \\ ${ }^{I}$ Physics Department, Faculty of Science, Suez University, Suez, Egypt \\ ${ }^{2}$ Nuclear Materials Authority, Cairo, El Maadi, Egypt
}

\begin{abstract}
Received $19^{\text {th }}$ Sep. 2018 The radiological hazard indices were determined using NaI(Tl) detector for twenty six collected rock Accepted 17 ${ }^{\text {th }}$ Mar. 2019 samples from Abu Rusheid area, South Eastern Desert, Egypt. The Eastern Desert of Egypt is a source of granitic rocks used for uranium mining and also used as raw materials for building.For this reason cataclastic (mylonitic) rock samlpes were investigated to evaluate the radiation hazard indicators and compare them with the world average values.The results show that the distribution of radionuclides activity concentrations in the rock sample varieties affects the values of the absorbed dose rate in the studied rocks to be higher than the worldwide limit that are not safe for human. The average values of the total annual effective dose varied from 3.30 to $7.51 \mathrm{mSvy}^{-1}$ and the lifetime cancer risk ranged from 2.31 to 5.25. From the radiation protection point, the results were found above the worldwide average. These data record the radioactivity background levels in rock samples and could be used as reference information to assess any changes in the radioactivity background level due to different geological processes in the investigated area.
\end{abstract}

Keywords: Gamma ray spectroscopy, Annual effective dose, Hazard indices, Rock samples

\section{Introduction}

The study of radionuclides and their generation in natural samples has become one of the most important issues due to its impact on human health, plant and animal. Gamma ray surveys are used in geological, geochemical and environmental mapping for mineral exploration, Natural radioactive elements such as uranium, thorium can be found everywhere in the world [1]. Natural radioactive materials such as uranium and thorium chains in addition to potassium are found in different percentages in soil, water, animal, human, oil and phosphate [2,3]. The variation in radionuclides concentrations of soil depends on the mineralogical composition, chemical composition, and physical properties [4]. All raw materials and products derived from rock and soil contain various amounts of mainly natural radionuclides elements.

Exposure to radiation is classified into: the external exposure as a result of gamma rays and the internal exposure due to the inhalation of radon, thoron and their progeny. These radionuclides are the sources of the external and the internal radiation exposures in dwellings, mining sites, nuclear facilities. The activities of radionuclides depend on geological and geographical conditions as well as geochemical characteristics of those materials. The importance of studying the radiation level and radionuclides distributions in our environment comes from the continuing human population growth and man made nuclear activities. The earth's natural

Corresponding author: korany81@hotmail.com

DOI: 10.21608/ajnsa.2019.5168.1121

(C) Scientific Information, Documentation and Publishing Office (SIDPO)-EAEA 
radiation comes from the presence of radioactive elements such as thorium, uranium and potassium in the environment at different levels due to geological and geographical conditions and is the main cause of external exposure due to the emission of gamma rays [5].

Many previous works have linked cancer with radiation from natural and non-natural sources. This includes lung cancer, breast and thyroid glands. Long exposures lead to a greater the risk of cancer, although it appears after decades of exposure and is no different from cancer caused by other factors [6]. Various human activities involving the use of radioactive materials and radiation tend to cause radiation exposure in addition to the natural exposure. An example of such activities includes mining, processing and the use of raw materials, which NORM. Many studies have investigated the radioactive elements in different rock samples. From the radiological point, the area under study attracted the attention of several authors $[5,7,8]$.

The present work aimed to assess the natural radionuclides and the radiological hazard indices in samples collected from Abu Rusheid area, which is used as an exploration area for uranium mining, and may also be used as building materials in the future, using $[\mathrm{NaI}(\mathrm{Tl})]$ gamma ray spectroscopy, to assess the radiological risk associated with among processing and the accumulated effluent in the investigated area.

\section{Geology of Abu Rusheid}

The area of Wadi Abu Rusheid, Wadi Nugrus and Wadi Sikait comprises two napes (ophiolite rocks and arc assemblage), separated by ophiolitic mélange. These rocks associations are intruded by intracratonic gabbroic and granitic rocks $[9,10]$. The rocks are generally intensively deformed and show clear gradual variation from low grade green schist facies, through the medium grade amphibolite facies (staurolite - kyanite - silliminite facies) [11]. It is mainly constituted of metaperidotites, meta-pyroxenites, layered metagabbros and ortho-amphibolites [12]. The detailed geologic of the study area $\left(3.0 \mathrm{~km}^{2}\right)$ is characterized by low to moderate topography.

Abu Rusheid granitic pluton is elongated in north west to south east (12 km in length) and is thinning in north east to the south west ( $3 \mathrm{~km}$ in width). The cataclastic rocks occupy the core of that granitic pluton. The granitic rocks are represented from the NW direction by porphyritic biotite granites followed by deformed biotite granites and two mica granites (abundant garnet and kyanite crystals), whereas the muscovite granites occupy the SE part of the pluton [7, 13].

\section{Materials and Methods}

Twenty six cataclastic (mylonitic) rock samples were collected from Abu Rusheid, South Eastern Desert, Egypt. The samples were analyzed by gamma ray spectroscopy $[\mathrm{NaI}(\mathrm{Tl})]$ to determine the natural radionuclides concentration and the radiological hazard indices for the studied area. The samples were collected at an equal distance of $50 \mathrm{~m}$ between each other, then dried in air for four days and Then dried at $105^{\circ}$ Cfor 4 hours to remove moisture completely.The samples were homogeneously crushed down to 200 mesh, which is the most suitable size for heavy minerals, and were put in circular plastic containers $10 \mathrm{~cm}$ diameter and $3 \mathrm{~cm}$ height, it is then closed for four weeks until equilibrium occurs between the parent and daughter nucleus [14]. To ensure that radon and radon decay products exist within the same sample. The measuring system consists of $\mathrm{NaI}(\mathrm{Tl})$ crystal, 76x76 mm detector housed in thick lead shield. The detector is also connected with PCA8000 computer based, 8192 multichannel analyzer. The gamma ray spectroscopy system was calibrated before it is used. The $1460 \mathrm{KeV}$ photo peak was used to evaluate the ${ }^{40} \mathrm{~K}$ activity, 1764 $\mathrm{KeV}$ gamma line of ${ }^{214} \mathrm{Bi}$ for ${ }^{226} \mathrm{Ra}$ and $2610 \mathrm{KeV}$ gamma line of ${ }^{208} \mathrm{Tl}$ for ${ }^{232} \mathrm{Th}$. The conversion values of $\mathrm{Ra}$, Th in ppm, as well as $\mathrm{K} \%$, were converted to activity concentration in $\mathrm{Bqkg}^{-1}$, by using the conversion factors given by the Polish Central Laboratory for Radiological Protection [15]. The spacific activity for $1 \mathrm{ppm}$ sample of ${ }^{226} \mathrm{Ra}$ equalized $11.1 \mathrm{Bqkg}^{-1}, 1 \mathrm{ppm}^{232} \mathrm{Th}$ is $4.06 \mathrm{~Bq}$ $\mathrm{kg}^{-1}$ and $1 \mathrm{~K} \%$ equal $313 \mathrm{Bqkg}^{-1}[16,17]$. Using radiation activity of radionuclides, the risk factor was calculated including ; radium equivalent activity, absorbed dose, annual effective dose, gamma index, external and internal hazard index, excess lifetime cancer risk and annual gonadal equivalent dose. These parameters are indicators of the health status of the human beings and environment. 
Radium equivalent activity $\left(R a_{\text {eq }}\right)$

The distribution of ${ }^{226} \mathrm{Ra},{ }^{232} \mathrm{Th}$ and ${ }^{40} \mathrm{~K}$ in soil has been defined in terms of radium equivalent $\left(\mathrm{Bqkg}^{-}\right.$ $\left.{ }^{1}\right)$, and it given by:

$$
R a_{e q}=A_{R a}+1.43 A_{T h}+0.077 A_{K}
$$

$\mathrm{Ra}_{\mathrm{eq}}$ is radium equivalent $\left(\mathrm{Bqkg}{ }^{-1}\right)$ and $\left(\mathrm{A}_{\mathrm{Ra}}-\mathrm{A}_{\mathrm{Th}}\right.$ $\left.\mathrm{A}_{\mathrm{K}}\right)$ are the specific activities of ${ }^{226} \mathrm{Ra}-{ }^{232} \mathrm{Th}$ $\left.{ }^{40} \mathrm{~K}\right)$ in $\mathrm{Bqkg}^{-1}[18,19]$.

\section{Absorbed dose rate (D)}

The absorbed dose rate in air (D) depends on the specific activity of ${ }^{226} \mathrm{Ra},{ }^{232} \mathrm{Th}$ and ${ }^{40} \mathrm{~K}$, was calculated using the following equation:

$$
D\left(n G y h^{-1}\right)=0.462 A_{R a}+0.604 A_{T h}+0.0417 A_{K}
$$

Where $\mathrm{D}$ is the absorbed dose rate $\left(\mathrm{nGyh}^{-1}\right)[6,20]$.

\section{Annual effective dose equivalent (AEDE)}

In this case, a conversion coefficient from the absorbed dose in air to the effective dose must take into account value of $0.7 \mathrm{SvGy}^{-1}$ a conversion factor from air intake to the effective dose received by adults, where the outdoor occupancy factor 0.2 and 0.8 for indoor occupancy factor. It was calculated using the equations [6]:

$$
\begin{aligned}
& A E D E_{\text {OUT }}=D\left(n G h^{-1}\right) \times 8760 h y^{-1} \times 0.7 \times 10^{-6} \times 0.2 \\
& A E D E_{\text {In }}=D\left(n G h^{-1}\right) \times 8760 h y^{-1} \times 0.7 \times 10^{-6} \times 0.8
\end{aligned}
$$

Tottal Annual effective dose $\left(m S v y^{-1}\right)=$

$$
A E D R_{\text {Outdoor }}+A E D R_{\text {Indoor }}
$$

Representative level index $\left(I_{\gamma}\right)$ :

Representative level index $\left(\boldsymbol{I}_{\gamma}\right)$ is the estimation of gamma radiation associated with the natural radionuclides $\left({ }^{226} \mathrm{Ra},{ }^{232} \mathrm{Th}\right.$ and $\left.{ }^{40} \mathrm{~K}\right)$ in the soil by this equation [21]:

$$
I(\gamma)=\frac{A_{R a}}{150}+\frac{A_{T h}}{100}+\frac{A_{K}}{1500}
$$

\section{External $\left(H_{e x}\right)$ and Internal hazardous index:}

In the case of constructing a building using materials with a percentage of radionuclides produced by an external radiation( external hazard index) dose and calculated from the following relationship.

$$
H_{e x}=\frac{A_{R a}}{370}+\frac{A_{T h}}{259}+\frac{A_{K}}{4810}
$$

Another hazard index, called the internal hazard index $\left(\mathrm{H}_{\text {in }}\right)$ that controls the internal exposure to radon and its radioactive progeny, was calculated using the equation:

$$
H_{\text {in }}=\frac{A_{R a}}{185}+\frac{A_{T h}}{259}+\frac{A_{K}}{4810}
$$

In order to ensure that there is any harmful effect, the value of internal and external indices should not exceed $1 \mathrm{mSvy}^{-1}$ to the population, and to keep the radiation hazard negligible[22, 23].

\section{Excess lifetime cancer risk (ELCR):}

Is the possibility of cancer development due to exposure to radiation, taking into account the average age of human 70 years was calculated from the following relationship:

$$
E L C R=A E D E \times D L \times R F
$$

Where DL is the average duration of a lifetime (estimated to be 70 years) and RF is the risk factor (Sv), for stochastic effects, assigned by ICRP as $0.05 / \mathrm{Sv}$ for the public [1].

\section{Annual Gonadal equivalent dose (AGED):}

Measurement of the threat resulting from the effect of a certain level of radiation on the gonads called annual gonadal equivalent dose and calculated from the following relationship[24].

$$
A G E D\left(m S v y^{-1}\right)=3.09 A_{R a}+4.18 A_{T h}+0.314 A_{K}
$$

\section{Results and Discussion}

The location of the collected samples and the activity concentration of ${ }^{226} \mathrm{Ra},{ }^{232} \mathrm{Th}$ and ${ }^{40} \mathrm{~K}$ and radium equivalent activity are evaluated and given in Table (1). The large variation of activity concentrations observed at different locations in study area refers to variables in the mineralogical content present in soil due to regional geology of the study area. Based on UNSCEAR recommendations for the activity values of ${ }^{226} \mathrm{Ra}$, ${ }^{232} \mathrm{Th}$ and ${ }^{40} \mathrm{~K}$ are 50, 50, and $500 \mathrm{Bqkg}^{-1}$, respectively, and also the value of radium equivalent activity is $370 \mathrm{Bqkg}^{-1}$ [25]. The average values in $\mathrm{ppm}$ for three natural nuclides equal $64.65,178.73 \mathrm{ppm}$ and $3.04 \%$ for ${ }^{226} \mathrm{Ra},{ }^{232} \mathrm{Th}$ and ${ }^{40} \mathrm{~K}$ respectively. However, the activity concentration of ${ }^{226} \mathrm{Ra}$ ranged from 133.2 to 1542.9 $\mathrm{Bqkg}^{-1}$ and the average value equal $717.66 \mathrm{Bqkg}^{-1}$. Also the activity concentration of ${ }^{232} \mathrm{Th}$ ranged from 682.08 to $2457.27 \mathrm{Bqkg}^{-1}$, and the average value equals $732.80 \mathrm{Bqkg}^{-1}$. But for ${ }^{40} \mathrm{~K}$ varied from 71.99 to $1521.18 \mathrm{Bqkg}^{-1}$, and the average value $1307.02 \mathrm{Bqkg}^{-1}$. The values of activity concentrations are higher than the world average of $35 \mathrm{Bqkg}^{-1}$ for ${ }^{226} \mathrm{Ra}, 30 \mathrm{Bqkg}^{-1}$ for ${ }^{232} \mathrm{Th}$ and 340 $\mathrm{Bqkg}^{-1}$ for ${ }^{40} \mathrm{~K}$ [6]. The comparison between the activity concentrations of ${ }^{226} \mathrm{Ra},{ }^{232} \mathrm{Th}$ and ${ }^{40} \mathrm{Kfor}$ 
the collected samples is shown in Figure1, which presents that the values of activity concentration of ${ }^{232} \mathrm{Th}$ are higher than the values of ${ }^{226} \mathrm{Ra}$ and ${ }^{40} \mathrm{~K}$, but the activity concentration of ${ }^{226} \mathrm{Ra}$ is lower than ${ }^{232} \mathrm{Th}$ and ${ }^{40} \mathrm{~K}$. Sample number 23 has a high value of ${ }^{232} \mathrm{Th}$ and sample number 1 has the lowest value of ${ }^{232} \mathrm{Th}$. Also sample number 22 has a high value of ${ }^{226} \mathrm{Ra}$ and the lowest value was found in sample 26 .

The higher value of ${ }^{40} \mathrm{~K}$ was found in sample, number 21 and the lowest value in sample 20. The results are useful for environmental mapping for mineral exploration. The values of radium equivalent activity varied from 1199.44 to 2725.41 $\mathrm{Bq} \mathrm{kg}{ }^{-1}$ with an average value $1838.84 \mathrm{~Bq} \mathrm{~kg}^{-1}$. The obtained results indicate that the values of radium equivalent activity for all samples are above the permissible limit of $370 \mathrm{~Bq} \mathrm{~kg}^{-1}$ which recommended by UNSCEAR. This may be attributed to the enrichment with ${ }^{238} \mathrm{U}$ [6]. The distribution of radionuclides activity concentrations in the rock samples are higher than the worldwide limit and not safety for human.

The correlation relation between radium equivalent activity and external hazard is shown in Figure (2), where the correlation factor $\left(\mathrm{R}^{2}=1\right)$ this is a positive relation and this is referred to the values of external hazard depend on gamma radiation, which emitted from ${ }^{226} \mathrm{Ra},{ }^{232} \mathrm{Th}$ and ${ }^{40} \mathrm{~K}$.

The external, internal hazard index, representative level index, absorbed dose rate, annual effective dose, excess lifetime cancer risk and annual gonadal dose equivalent rate of the collected samples are given in Table (2). The representative level index ranges from 8.15 to 16.91 with an average value of 12.75 . The average of $\left(\boldsymbol{I}_{\gamma}\right)$ is higher than the international accepted value of 1 $\mathrm{Bqkg}^{-1}$. The average external hazardous $\left(\mathrm{H}_{\mathrm{ex}}\right)$ value for the investigated samples was 4.97 , which higher than unity [23]. The average internal hazardous $\left(\mathrm{H}_{\text {in }}\right)$ value for the investigated samples was 6.46 , this value is higher than unity [26]. It should be taken into consideration that the $\mathrm{H}_{\mathrm{ex}}$ and $H_{\text {in }}$ risk values must be less than unity [14]. The external, internal hazard index and the representative gamma index are higher than the world permissible value of unity [27]. The average values of calculated absorbed dose rates in cataclastic rock samples under investigation range between 537.62 to $1223.95 \mathrm{nGyh}^{-1}$ with an average value $813.86 \mathrm{nGyh}^{-1}$ is higher than the value 55 $\mathrm{nGyh}^{-1}$, which recommended by UNSCEAR [6]. The worldwide average values ranged from 18 to $93 \mathrm{nGy} \mathrm{h}^{-1}$. The measured absorbed dose rate in outdoor air ranged from 10 to $200 \mathrm{nGy} \mathrm{h}^{-1}$. The population average value of absorbed dose of terrestrial gamma radiation equal $55 \mathrm{nGyh}^{-1}$. The average annual dose (oudoor) from the collected samples was $1 \mathrm{mSv} \mathrm{y}^{-1}$, while for the indoor value was $3.35 \mathrm{mSv} \mathrm{y}^{-1}$ with a total average annual dose of $4.99 \mathrm{mSv} \mathrm{y}^{-1}$. It is found that the average annual dose is higher than the recommended value. The comparison between the sample number and total annual effective dose for the collected samples given by Figure3, since sample number 22 has a high value but the lowest value found in sample number 20. If the excessive gamma radiation due to those materials causes the increase of the annual effective dose received by an individual with a maximum value.

An effective dose exceeding the dose criterion of $1 \mathrm{mSvy}^{-1}$ should be taken into account in terms of radiation protection. The correlation between representative level index and excess lifetime cancer risk is given in Figure4. This is a positive correlation, which equal $R^{2}=1$. The figure indicates that lifetime cancer risk increases with increasing exposure to level index of gamma. The average excess lifetime cancer risk equal 3.49 exceeded the global average of $0.29 \times 10^{-3}$. The AGED is higher than the permissible limit of $300 \mathrm{mSvy}^{-1}$ [28]. Positive correlation was found between representative level index and annual gonadal dose equivalent rate $\left(R^{2}=0.99\right)$ as shown in Figure (5). No dose should exceed $50 \mathrm{mSvR}$ based on the recommendations of the International Committee for Radiation Protection from all sources, whether industrial or nature, as well as the recommendations of the International Atomic Energy Agency[29]. The permissible levels of dose reaches up to $5 \mathrm{mSv} \mathrm{y}^{-1}$ for public members and up to $20 \mathrm{mSv} \mathrm{y}^{-1}$ for the occupational members. The obtained results agree with the published data of different authors[6,16,18, and 30-38], and it is given in Table (3). 
Table (1): Position, content in (ppm), activity concentration and radium equivalent in $\left(\mathrm{Bqkg}^{-1}\right)$ for the collected rock

\begin{tabular}{|c|c|c|c|c|c|c|c|c|c|}
\hline \multirow{3}{*}{$\begin{array}{l}\text { S. } \\
\text { No. }\end{array}$} & & & \multirow{2}{*}{\multicolumn{2}{|c|}{ Ra-226 }} & \multirow{2}{*}{\multicolumn{2}{|c|}{ Th-232 }} & \multirow{2}{*}{\multicolumn{2}{|c|}{ K-40 }} & \\
\hline & \multirow{2}{*}{ Lat. } & \multirow{2}{*}{ Long. } & & & & & & & \multirow{2}{*}{$\begin{array}{l}\mathbf{R a}_{\mathrm{eq}} \\
\mathbf{B q ~ k g}^{-1}\end{array}$} \\
\hline & & & ppm* & Bq kg ${ }^{-1}$ & ppm* & Bq kg ${ }^{-1}$ & ppm* & Bq $\mathbf{k g}^{-1}$ & \\
\hline 1 & $678917 \mathrm{E}$ & $2725791 \mathrm{~N}$ & 44 & 488.4 & 168 & 682.08 & 3.12 & 976.56 & 1548.58 \\
\hline 2 & $678945 \mathrm{E}$ & $2725783 \mathrm{~N}$ & 51 & 566.1 & 251 & 1548.58 & 4.1 & 1283.3 & 2136.53 \\
\hline 3 & $679006 \mathrm{E}$ & $2725804 \mathrm{~N}$ & 79 & 876.9 & 209 & 2136.53 & 2.15 & 672.95 & 2154.08 \\
\hline 4 & $679029 \mathrm{E}$ & $2725785 \mathrm{~N}$ & 69 & 765.9 & 244 & 2154.08 & 2.74 & 857.62 & 2262.51 \\
\hline 5 & $678971 \mathrm{E}$ & $2725785 \mathrm{~N}$ & 31 & 344.1 & 156 & 2262.51 & 2.52 & 788.76 & 1319.46 \\
\hline 6 & $678941 \mathrm{E}$ & $2725811 \mathrm{~N}$ & 50 & 555 & 252 & 1319.46 & 2.47 & 773.11 & 2092.01 \\
\hline 7 & $678897 \mathrm{E}$ & $2725824 \mathrm{~N}$ & 103 & 1143.3 & 214 & 2092.01 & 2.46 & 769.98 & 2457.27 \\
\hline 8 & $678935 \mathrm{E}$ & $2725751 \mathrm{~N}$ & 85 & 943.5 & 200 & 2457.27 & 2.35 & 735.55 & 2172.74 \\
\hline 9 & $678890 \mathrm{E}$ & $2725721 \mathrm{~N}$ & 49 & 543.9 & 125 & 2172.74 & 2.67 & 835.71 & 1341.12 \\
\hline 10 & $678860 \mathrm{E}$ & $2725764 N$ & 59 & 654.9 & 245 & 1341.12 & 3.83 & 1198.79 & 2183.64 \\
\hline 11 & $678748 \mathrm{E}$ & $2725729 \mathrm{~N}$ & 62 & 688.2 & 225 & 2183.64 & 2.64 & 826.32 & 2071.00 \\
\hline 12 & $678739 \mathrm{E}$ & $2725757 \mathrm{~N}$ & 55 & 610.5 & 213 & 2071.00 & 3.32 & 1039.16 & 1939.33 \\
\hline 13 & $678722 \mathrm{E}$ & $2725809 \mathrm{~N}$ & 61 & 677.1 & 117 & 1939.33 & 2.87 & 898.31 & 1432.24 \\
\hline 14 & $678676 \mathrm{E}$ & $2725838 \mathrm{~N}$ & 74 & 821.4 & 129 & 1432.24 & 2.64 & 826.32 & 1641.35 \\
\hline 15 & 678964E & $2725252 \mathrm{~N}$ & 105 & 1165.5 & 115 & 1641.35 & 3.72 & 1164.36 & 1929.40 \\
\hline 16 & $679067 \mathrm{E}$ & $2725233 \mathrm{~N}$ & 72 & 799.2 & 122 & 1929.40 & 3.52 & 1101.76 & 1599.32 \\
\hline 17 & $679119 \mathrm{E}$ & $2725188 \mathrm{~N}$ & 45 & 499.5 & 181 & 1599.32 & 3.39 & 1061.07 & 1642.41 \\
\hline 18 & $679189 \mathrm{E}$ & $2725255 \mathrm{~N}$ & 55 & 610.5 & 272 & 1642.41 & 2.57 & 804.41 & 2267.18 \\
\hline 19 & 678999E & $2725175 \mathrm{~N}$ & 53 & 588.3 & 102 & 2267.18 & 2.39 & 748.07 & 1243.93 \\
\hline 20 & $679131 \mathrm{E}$ & $2725036 \mathrm{~N}$ & 69 & 765.9 & 73 & 1243.93 & 0.23 & 71.99 & 1199.44 \\
\hline 21 & $679073 \mathrm{E}$ & $2725065 \mathrm{~N}$ & 41 & 455.1 & 123 & 1199.44 & 5.00 & 1565 & 1296.75 \\
\hline 22 & $679113 \mathrm{E}$ & $2724964 N$ & 139 & 1542.9 & 185 & 1296.75 & 4.06 & 1270.78 & 2725.41 \\
\hline 23 & $679069 \mathrm{E}$ & $2724856 \mathrm{~N}$ & 94 & 1043.4 & 117 & 2725.41 & 4.86 & 1521.18 & 1846.50 \\
\hline 24 & $679028 \mathrm{E}$ & $2724855 \mathrm{~N}$ & 57 & 632.7 & 173 & 1846.50 & 2.52 & 788.76 & 1707.73 \\
\hline 25 & $678978 \mathrm{E}$ & $2724784 \mathrm{~N}$ & 67 & 743.7 & 248 & 1707.73 & 3.95 & 1236.35 & 2292.92 \\
\hline 26 & $679023 \mathrm{E}$ & $2724736 \mathrm{~N}$ & 12 & 133.2 & 188 & 2292.92 & 2.97 & 929.61 & 1307.02 \\
\hline Ave & & & 64.65 & 717.66 & 178.73 & 732.80 & 3.04 & 1307.02 & 1838.84 \\
\hline
\end{tabular}

*The percentage of error in the content in ppm equal $\pm 10 \%$ 


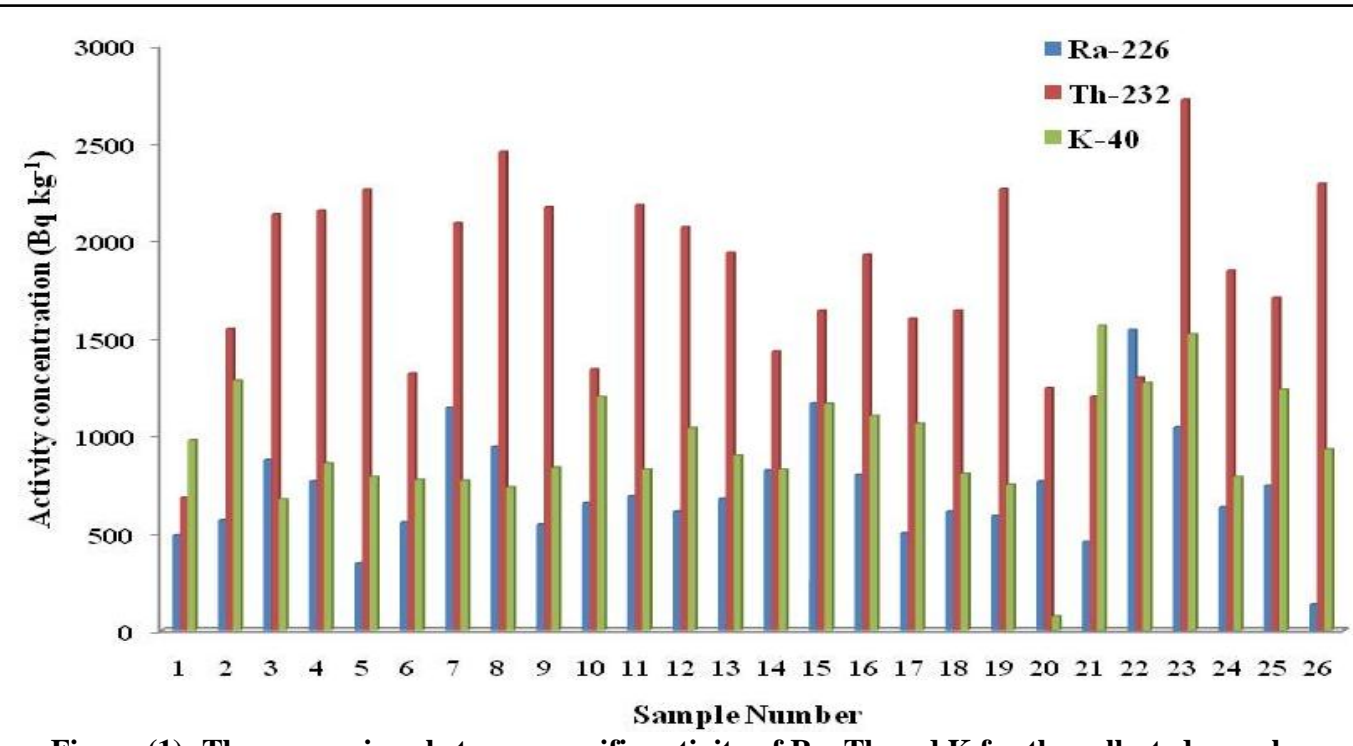

Figure (1): The comparison between specific activity of Ra, Th and $\mathrm{K}$ for the collected samples

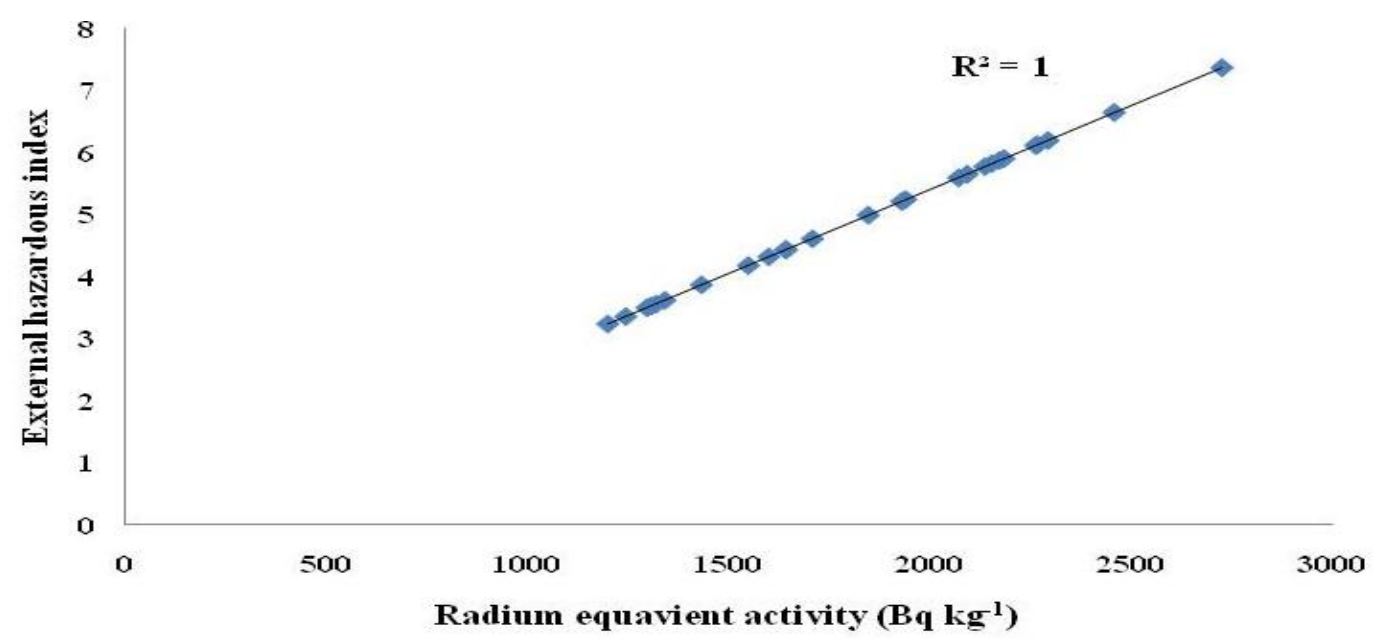

Figure (2): The relation between radium equavlent activity and external hazard index for the collected samples

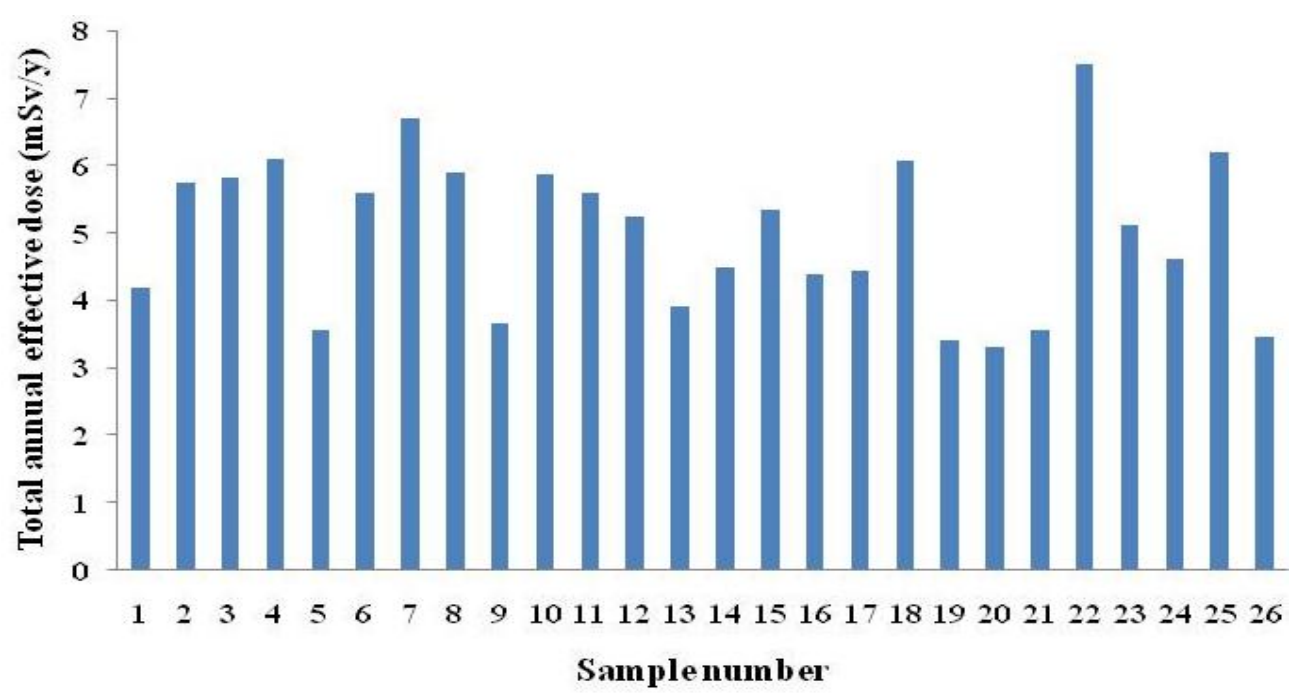

Figure (3): The comparison between the values of the total annual effective dose for the collected samples 
Table (2): External, internal hazard index, representative level index, $D_{R}, A E D$, ELCR and AGED of the collected samples

\begin{tabular}{|c|c|c|c|c|c|c|c|c|c|}
\hline \multirow{3}{*}{$\begin{array}{l}\text { Sample } \\
\text { No. }\end{array}$} & \multicolumn{2}{|c|}{ Hazard index } & \multirow{3}{*}{ I (y) } & \multirow{3}{*}{$\begin{array}{l}\mathrm{D}_{\mathrm{R}} \\
\left(\mathrm{nGyh}^{-1}\right)\end{array}$} & \multicolumn{3}{|c|}{$\begin{array}{lll}\begin{array}{l}\text { Annual } \\
\left(\mathrm{mSvy}^{-1}\right)\end{array} & \text { Effective } & \text { dose } \\
\end{array}$} & \multirow{3}{*}{ ELCR } & \multirow{3}{*}{ AGED } \\
\hline & \multirow[b]{2}{*}{$\mathrm{H}_{\text {in }}$} & \multirow[b]{2}{*}{$\mathrm{H}_{\mathrm{ex}}$} & & & & $\mathrm{A}_{\mathrm{d}}$ & $A_{d}$ & & \\
\hline & & & & & outdoor & indoor & total & & \\
\hline 1 & 5.50 & 4.18 & 10.80 & 682.40 & 0.84 & 3.35 & 4.18 & 2.93 & 4694.98 \\
\hline 2 & 7.30 & 5.77 & 14.92 & 936.63 & 1.15 & 4.59 & 5.74 & 4.02 & 6453.84 \\
\hline 3 & 8.19 & 5.82 & 14.86 & 950.76 & 1.17 & 4.66 & 5.83 & 4.08 & 6502.77 \\
\hline 4 & 8.18 & 6.11 & 15.68 & 993.85 & 1.22 & 4.88 & 6.09 & 4.27 & 6817.60 \\
\hline 5 & 4.49 & 3.56 & 9.22 & 578.18 & 0.71 & 2.84 & 3.55 & 2.48 & 3984.47 \\
\hline 6 & 7.15 & 5.65 & 14.55 & 912.70 & 1.12 & 4.48 & 5.60 & 3.92 & 6276.48 \\
\hline 7 & 9.73 & 6.64 & 16.91 & 1090.26 & 1.34 & 5.35 & 6.69 & 4.68 & 7442.10 \\
\hline 8 & 8.42 & 5.87 & 14.98 & 961.85 & 1.18 & 4.72 & 5.90 & 4.13 & 6573.98 \\
\hline 9 & 5.09 & 3.62 & 9.31 & 595.68 & 0.73 & 2.92 & 3.65 & 2.56 & 4085.31 \\
\hline 10 & 7.67 & 5.90 & 15.21 & 959.27 & 1.18 & 4.71 & 5.88 & 4.12 & 6598.87 \\
\hline 11 & 7.45 & 5.59 & 14.36 & 909.60 & 1.12 & 4.46 & 5.58 & 3.90 & 6242.05 \\
\hline 12 & 6.89 & 5.24 & 13.50 & 852.86 & 1.05 & 4.18 & 5.23 & 3.66 & 5863.14 \\
\hline 13 & 5.70 & 3.87 & 9.91 & 640.02 & 0.78 & 3.14 & 3.92 & 2.75 & 4379.45 \\
\hline 14 & 6.65 & 4.43 & 11.32 & 733.40 & 0.90 & 3.60 & 4.50 & 3.15 & 5008.39 \\
\hline 15 & 8.36 & 5.21 & 13.26 & 871.80 & 1.07 & 4.28 & 5.35 & 3.74 & 5937.87 \\
\hline 16 & 6.48 & 4.32 & 11.06 & 717.29 & 0.88 & 3.52 & 4.40 & 3.08 & 4906.32 \\
\hline 17 & 4.84 & 4.44 & 11.46 & 723.24 & 0.89 & 3.55 & 4.43 & 3.10 & 4978.61 \\
\hline 18 & 4.58 & 6.12 & 15.76 & 989.18 & 1.21 & 4.85 & 6.07 & 4.25 & 6800.57 \\
\hline 19 & 4.34 & 3.36 & 8.60 & 555.58 & 0.68 & 2.73 & 3.41 & 2.38 & 3800.82 \\
\hline 20 & 3.22 & 3.24 & 8.15 & 537.62 & 0.66 & 2.64 & 3.30 & 2.31 & 3640.31 \\
\hline 21 & 6.03 & 3.50 & 9.12 & 580.11 & 0.71 & 2.85 & 3.56 & 2.49 & 4005.64 \\
\hline 22 & 9.53 & 7.36 & 18.72 & 1223.95 & 1.50 & 6.00 & 7.51 & 5.25 & 8337.12 \\
\hline 23 & 8.23 & 4.99 & 12.77 & 835.22 & 1.02 & 4.10 & 5.12 & 3.59 & 5706.90 \\
\hline 24 & 4.63 & 4.61 & 11.84 & 753.62 & 0.92 & 3.70 & 4.62 & 3.23 & 5167.59 \\
\hline 25 & 6.28 & 6.19 & 15.95 & 1009.29 & 1.24 & 4.95 & 6.19 & 4.33 & 6936.47 \\
\hline 26 & 3.04 & 3.53 & 9.22 & 565.87 & 0.69 & 2.78 & 3.47 & 2.43 & 3925.43 \\
\hline Avg. & 6.46 & 4.97 & 12.75 & 813.86 & 1.00 & 3.35 & 4.99 & 3.49 & 5579.50 \\
\hline
\end{tabular}

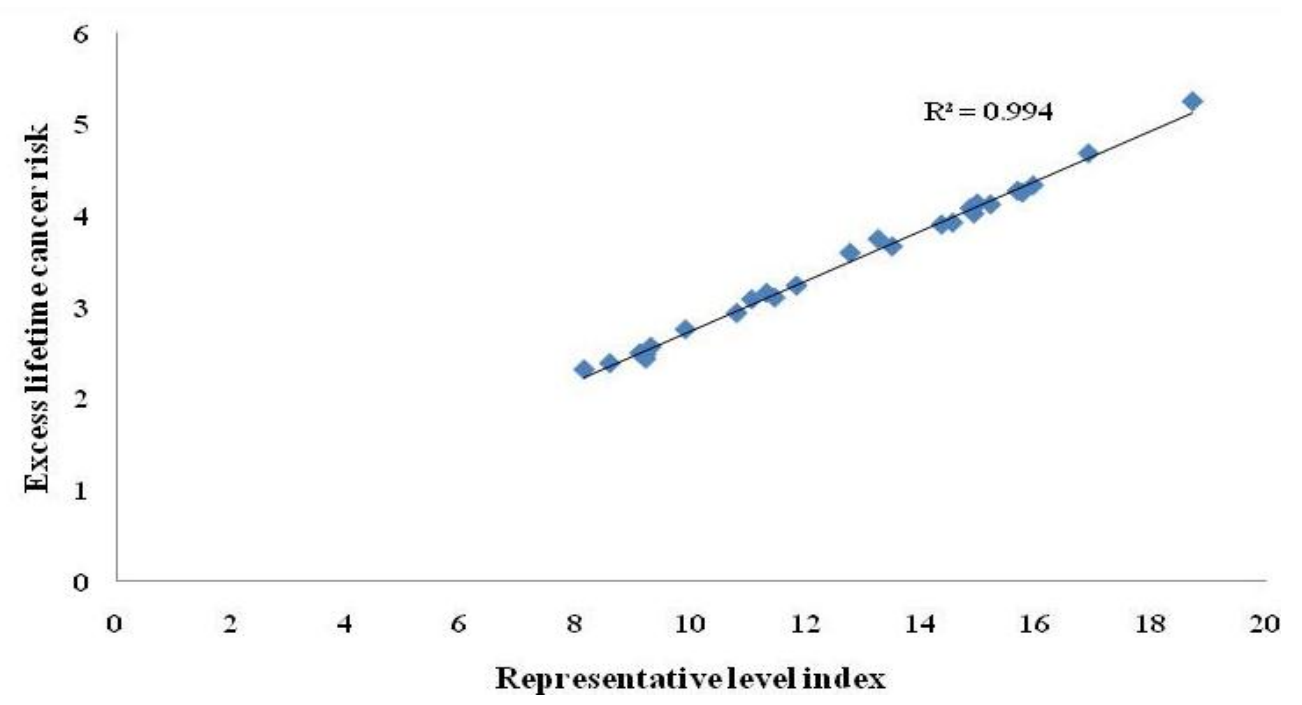

Figure (4): The relation between representative level index and life time cancer for the collected samples 


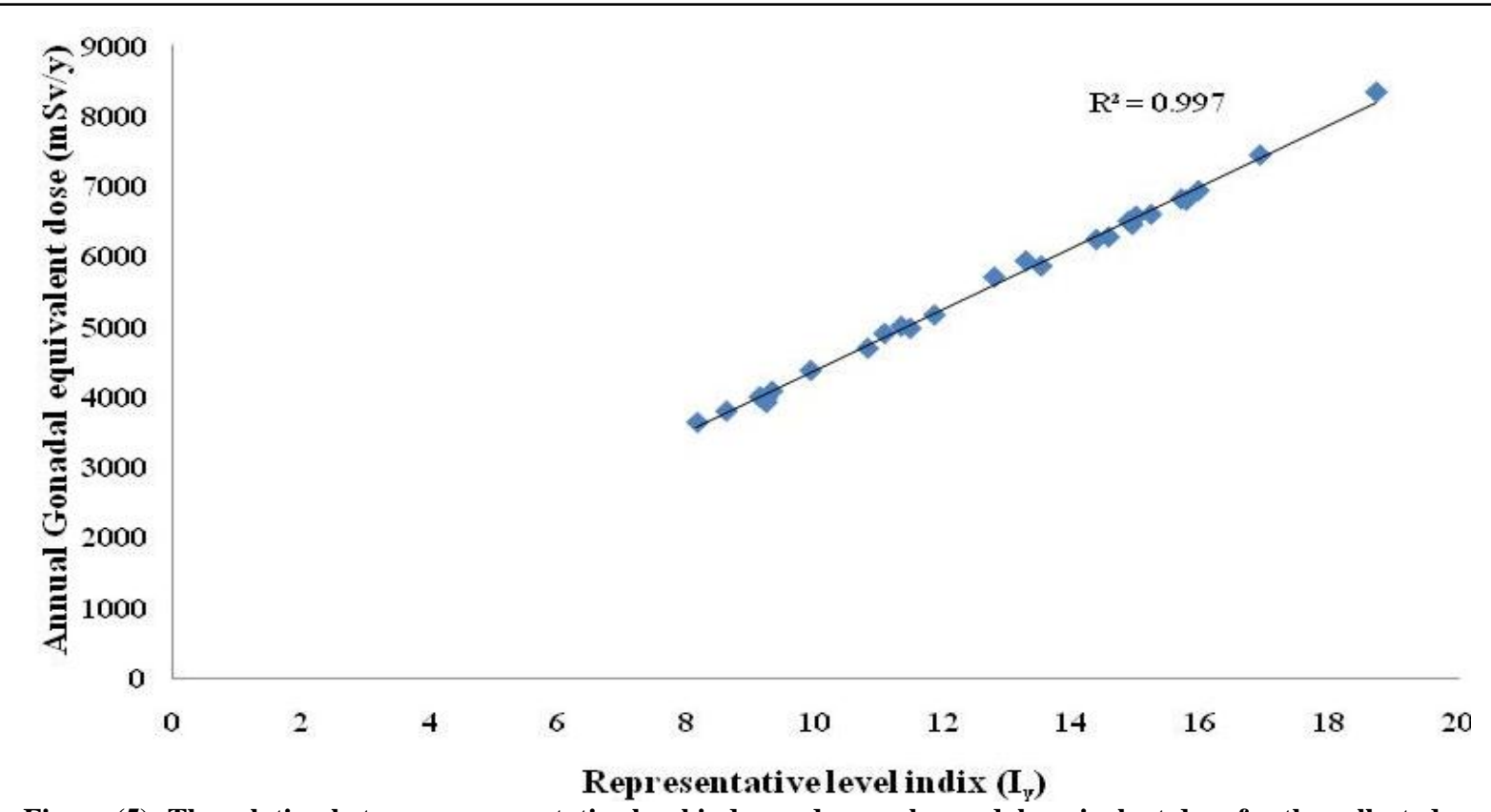

Figure (5): The relation between representative level index and annual gonadal equivalent dose for the collected samples

Table (3): A comparison between the obtained results and the published data

\begin{tabular}{|c|c|c|c|c|c|}
\hline \multirow{3}{*}{ Country/Org. } & & rom differ & ountries & \multirow{3}{*}{$\begin{array}{l}\mathbf{D}_{\mathbf{R}} \\
\left(\mathrm{nGyh}^{-1}\right)\end{array}$} & \multirow{3}{*}{ References } \\
\hline & ${ }^{226} \mathbf{R a}$ & ${ }^{232} \mathrm{Th}$ & ${ }^{40} K$ & & \\
\hline & \multicolumn{3}{|l|}{$\mathrm{Bq} \mathrm{kg}^{-1}$} & & \\
\hline $\begin{array}{l}\text { Egypt (Granite) } \\
\text { Gabal El Majal } \\
\text { Gabal El Misikat } \\
\text { Gabal El Aradia }\end{array}$ & $\begin{array}{l}239.96 \\
1308.78 \\
197.41\end{array}$ & $\begin{array}{l}30.3 \\
40.4 \\
24.5\end{array}$ & $\begin{array}{l}681.2 \\
704.7 \\
480.1\end{array}$ & $\begin{array}{l}134.1 \\
90.5 \\
569.9\end{array}$ & [30] \\
\hline Egypt (Granite) & 14.12 & 14.46 & 405.73 & 32.50 & [31] \\
\hline $\begin{array}{l}\text { Egypt (Soil - rocks) } \\
\text { Wadi Sahu }\end{array}$ & 378.47 & 65.75 & 243.05 & 222.71 & [16] \\
\hline Egypt (Rocks) & 98.8 & 15.23 & 77.86 & 61.9 & {$[32]$} \\
\hline Egypt (Granite) & 199.97 & 36.39 & 1051.61 & 150.53 & [33] \\
\hline $\begin{array}{ll}\text { Saudi } & \text { Arabia } \\
\text { (Granite) } & \end{array}$ & 76.4 & 81 & 1099 & $28-120$ & {$[34]$} \\
\hline Bangladesh (Soil) & 55.25 & 125.27 & 497.9 & 124.12 & [35] \\
\hline Iran (Rocks) & 14.8 & 5.5 & 148.41 & 14.39 & [36] \\
\hline Nigeria (Rocks) & 310 & 147.26 & 719.90 & 260 & [18] \\
\hline IAEA & 50 & 50 & 500 & & [37] \\
\hline ICRP & 35 & 30 & 400 & & [38] \\
\hline UNSCEAR & 35 & 30 & 400 & & [6] \\
\hline Egypt & 717.66 & 732.80 & 1307.02 & 826.31 & Present work \\
\hline
\end{tabular}

\section{Conclusions}

Radioactivity levels of the environment depend on the geological aspects of rock samples, where they are found in varying concentrations. The chemical and physical properties play an important role in the redistribution of radionuclides in different rock types. This distribution of radionuclides reflects its impacts on the environment. The Eastern Desert of Egypt is a source of granitic rocks used in uranium mining and also used as raw materials for building, and for that reason cataclastic (mylonitic) rock samples were investigated to evaluate the radiation 
hazard indicators and compare the values of the world average values. The present work contributes in establishing a database reference of natural radionuclide concentrations. The average activity concentration of radionuclides ${ }^{238} \mathrm{U},{ }^{232} \mathrm{Th}$ and ${ }^{40} \mathrm{~K}$ are higher than the world average values. The distribution of radionuclides activity concentrations in the rock sample varieties affects the values of the absorbed dose rate in the studied rocks and it is higher than the worldwide limit and are not safe for human. The annual effective dose rate exceeded the public permissible values in the studied rock samples, consequently, personal protective masks should be used to protect working personnel from inhalation of alpha particles. This means that these rocks are not safe for human beings from the environmental point of view. From the obtained results we can conclude that the area under study can be used as a mine of natural radioactive elements, and for point of safety, we must protect ourselves from radiation and don't live near the area under study to minimize the exposure time of radiation, and we must repeat the measurements to detect the variation in the concentration of radioactive radionuclides that affect the environment and human.

\section{References}

1-Carmen Grisel Mendez-Garcia, Elizabeth Teresita Romero-Guzman, Hector Hernandez-Mendoza, Corina Solis-Rosales and Efrain Rafael ChavezLomel1. (2017) Assessment of the concentrations of $\mathrm{U}$ and $\mathrm{Th}$ in $\mathrm{PM}_{2.5}$ from Mexico City and their potential human health risk. J Radioanal Nucl Chem (2017) 314:1767-1775. doi.org/10.1007/s10967-0175549-7.

2-Attallah M. F., Awwad N. S. and Aly H. F. (2012) Environmental radioactivity of TE-NORM waste produced from petroleum industry in Egypt: Review on characterization and treatment hot laboratories and waste management center, Atomic Energy Authority, Cairo, Egypt.

3-Amanjeet, Ajay Kumar, Suneel Kumar, Joga Singh, Parminder Singh, Bajwa B.S. (2017) Assessment of natural radioactivity levels and associated dose rates in soil samples from historical city Panipat, India. J Radiat Res Appl Sci, 10: 283-288. doi.org/10.1016/j.jrras.2017.05.006

4- Van Thang Nguyen, Ngoc Ba Vu, and Nguyen Phong Thu Huynh (2017) Gross alpha and beta radioactivity in food crops and surface soil from Ho Chi Minh City, Vietnam. J. Radioanal Nucl Chem: doi. 10.1007/s10967-017-5631-1.
5-Arafat A. A., Salama M. H. M., El-Sayed S. A., and Elfeel A. A. (2017) Distribution of natural radionuclides and assessment of the associated hazards in the environment of Marsa Alam-Shalateen area, Red Sea coast, Egypt. J Radiat Res Appl Sci, 10: 219-232. .doi.org/10.1016/j.jrras.2016.11.006

6-UNSCEAR (2000) United Nation Scientific Committed on the Effect of Atomic Radiation. Sources, Effects and Risks of Ionizing Radiation, Report to the General Assembly, New York.

7- Hesham A. Yousef, and Gehad M. Saleh (2013) Measurement of the natural radioactivity in cataclastic rock samples using RS-230 spectrometer. Greener J Phys Sci, 3(5): 165-176.

8-Hamid A., El khameesy S. U., Afifi S.Y., and Dabbour A. (2014) Elemental and radioactivity assessment in some environmental samples in South Eastern Desert of Egypt. Arab J Nucl Sci Appl, 47(3): 117-123.

9-Ibrahim M. A., Assaf H. S., and Saleh, G. M., (2000) Geochemical alteration and spectrometric analysis in Abu Rusheid altered uraniferous gneissose granites, South Eastern Desert, Egypt. Chem., Erde, 60:173188.

10-Saleh G. M. (1997) The potentiality of uranium occurrences in wadi- Nugrus area, south Eastern Desert, Egypt.Ph.D. Thesis, Faculty of Sci. Mansoura Univ. pp 171.

11-Surour A. A. (1995) Medium to high-pressure garnet-amphibolites from Gebel Zabara and Wadi Sikeit, South Eastern Desert, Egypt. J. Earth Sci. 21(3): 434 - 457.

12-Saleh G. M., Ibrahim I. H., Mahmoud, F. O., Abu El Hassan A. A., Rashed M. A., Khalel F. M., Mahmoud M.A., and others, (2010) Uranium potentiality of Abu Rusheid area, South Eastern Desert, Egypt. (Internal report).

13- Ibrahim M. E., Saleh G. M., Ibrahim I. H., Amer T, Mahmoud F. O., Abu El Hassan A. A., Aly M. A., Azab M. S., Rashed M. A., Khaleal F. M. and Mahmoud M. A. (2004) Uranium and associated rare metals potentialities of Abu Rusheid brecciated shear zone II, south Eastern Desert, Egypt. (Internal report).

14-Gallyas M and Torok I, (1984) Natural radioactivity of raw materials and products in the cement industry, Radiat. Prot. Dosim 7:69-71.

15-Malczewski D., Taper L., Dorda J. (2004) Assessment of natural and anthropogenic radioactivity level in rocks and soils in the environs of Swieradow Zdroj in student, Poland by in situ gamma-ray spectrometry. J. Environ . Radioact 73: 233-245.

16-Said A. F., Salam, A. M., Hassan, S. F. and Mohamed, W. S. (2010) Assessment of the environmental radioactivity impacts and healthy hazards indices at Wadi Sahu Area, Sinai, Egypt. 
Tenth Radiation Physics \& Protection Conference, 27-30 November, Naser City-Cairo, Egypt.

17-IAEA (2003) International Atomic Energy Agency. Guidelines for radioelement mapping using gamma rayspectrometry data : TECDOC-1363, Vienna.

18-Gbenu S.T., Oladejo O. F., Alayande O., Olukotun S. F., Fasasi M. K., Balogun F. A. (2015) Assessment of radiological hazard of quarry products from southwest Nigeria.J. Radiat Res Appl Sci. 9: 20-25.

19-Umesha Reddy K., Ningappa C., and Sannappa J. (2017) Natural radioactivity level in soils around Kolar Gold Fields, Kolar district, Karnataka, India. J Radioanal Nucl Chem 314:2037-2045. doi.org/10.1007/s10967-017-5545-y.

20-Ashraf E. M. K, Layia H. A., Amany A. A., and AlOmran A. M. (2010) NORM in clay deposits.Proceedings of Third European IRPA Congress 2010 June,14-18, Helsinki, Finland, 1-9.

21- Alam M. N., Chowdhury M. I., Kamal M., Ghose S., and Ismal M. N. (1999) The ${ }^{226} \mathrm{Ra},{ }^{232} \mathrm{Th}$ and ${ }^{40} \mathrm{~K}$ activities in beach sand minerals and beach soil of Cox's Bazer, Bangladesh. J Environ Radioact, 46(2):243- 250.

22-Ec (1999) Europen Commission. Radiation protection Unit, Radiological protection principle concentration the nature radioactivity of building materials. Radiation protection 112.

23-Diab H. M., Nouh S. A., Hamdy A., and El-Fiki S. A. (2008) Evaluation of natural radioactivity in a cultivated area around a fertilizer factory. J Nucl Radiat Phy, 3(1): 53-62.

24-Ajibode M. O., Avwiri G. O., and Agbalagba E. O., (2013) Evaluation of radiation hazard indices in oil mineral lease in Delta State, Nigeria. Environ Sci Indian J, 8(10):387-395.

25-UNSCEAR (2008). United Nations, and Scientific Committee on the Effects of Atomic Radiation. Report of the united Nations scientific committee on the effects of atomic radiation: Fifty-sixth Session. United Nations Publications (10-18 July 2008) (No. 46).

26-Iqbal M., Tuail M., Mirza M. S., (2000) Measurments of natural radioactivity in marble found in Pakistan using a $\mathrm{NaI}(\mathrm{Tl})$ gamma-ray spectrometer. J Environ Radioact, (51): 255-265.

27-Orgun Y., Altinsoy N., Sahin S. Y., Gungor Y., Gultekin A. H., Karaham G., and Karaak Z. (2007) Natural and anthropogenic radionuclide in rocks and beach sands from Ezine region, Western Anatolia,
Turkey.J Appl Radiat Isotop, 65: 739-747. Doi.org/10.1016/ j.apraiso.2006.06.011.

28-Taskin H. M, Karavus, P., Ay, A., Touzogh, S., Hindiroglu and Karaham, G. (2009) Radionuclide concentration in soil and lifetime cancer risk due to the gamma radioactivity in Kirklareli, Turkey.J Environ Radioact, 100: 49-53.

29-IAEA (1996) International Atomic Energy Agency. Internal Basic Safety standards for protection against Ionization radiation and for safety of radiation sources: Safety series, No.115.

30-Arafa Wafaa (2003) Specific activity and hazards of granite samples collected from the eastern Desert of Egypt. J of Environ Radioact, 75:315-327.

31- Harb S., El-Kamel A. H., Abd El-Mageed A. I., Abbady A., and Wafaa Rashed (2008) Concentration of U-238, U-235, Ra-226, Th-232 and K-40 for some Granite sample in Eastern desert of Egypt. Proceedings of the 3rd Environmental Physics Conference, 19-23 Feb. 2008, Aswan, Egypt.

32- El-Taher A. (2011) Assessment of Natural Radioactivity leves and Radiation Hazards for Building Materials Used in Qassim Area, Saudia Arabia, J Phys., 57( 3-4): 726-735.

33- Alharbi W. R., AlZahrani I. J. and Adel G.E. Abbady (2011) Assessment of Radiation Hazard Indices from Granite Rocks of the Southeastern Arabian Shield, Kingdom of Saudi Arabia. Australian J Basic Appl Sci, 5(6): 672-682.

34-Hassan A. K., Fares S. and Abd El-Rahma M. (2013) Natural Radioactivity level and Radiation Hazards for Gypsum materials used in Egypt. J Environ Sci Techny, DOI: 10.3923.

35- Miah Alamgir, Miah M. H., Masud Kamal, M. I. Chowdhury, M. Rahmatullah, (2012) Natural radioactivity and associated dose rates in Soil Samples of Malnichera Tea Garden in Sylhet District of Bangladesh. J Nucl Parti Phys, 2(6): 147-152.

36-Amiri J., Seyed Pezhman Shirmardi S. P., Eslamian J. P. (2014) Measuring natural radioactivity of bricks used in the constructions of Tehran. J Paramedical Sci, 5: 58-62.

37-IAEA (1991) International Atomic Energy Agency: Airborn Gamma ray spectrometer surveying, Technical report series, No. 390, IAEA, Vienna.

38- ICRP (1979) Recommendation of the international commission on radiologoical protection atomic energy agency, Technical reports series. No (45), Pergamon press, Oxford. 